\title{
Overexpression of BdMATE Gene Improves Aluminum Tolerance in Setaria viridis
}

\author{
Ana P. Ribeiro ${ }^{1,2}$, Wagner R. de Souza ${ }^{1}$, Polyana K. Martins ${ }^{1}$, Felipe Vinecky ${ }^{1}$, \\ Karoline E. Duarte', Marcos F. Basso', Bárbara A. D. B. da Cunha', \\ Raquel B. Campanha ${ }^{3}$, Patrícia A. de Oliveira ${ }^{3}$, Danilo C. Centeno ${ }^{4}$, \\ Geraldo M. A. Cançado ${ }^{5}$, Jurandir V. de Magalhães ${ }^{6}$, Carlos A. F. de Sousa ${ }^{1}$, \\ Alan C. Andrade ${ }^{2,7}$, Adilson K. Kobayashi' and Hugo B. C. Molinari ${ }^{1 *}$
}

OPEN ACCESS

Edited by:

Gabino Ríos,

Instituto Valenciano

de Investigaciones Agrarias, Spain

Reviewed by:

Qi Chen,

Kunming University of Science and Technology, China Jian Li Yang,

Zhejiang University, China

Manoj Prasad,

National Institute of Plant Genome

Research, India

*Correspondence:

Hugo B. C. Molinari

hugo.molinari@embrapa.br

Specialty section:

This article was submitted to

Plant Biotechnology,

a section of the journal

Frontiers in Plant Science

Received: 14 March 2017

Accepted: 09 May 2017

Published: 08 June 2017

Citation:

Ribeiro AP, de Souza WR

Martins PK, Vinecky F, Duarte $K E$,

Basso MF, da Cunha BADB,

Campanha RB, de Oliveira $P A$,

Centeno DC, Cançado GMA,

de Magalhães JV, de Sousa CAF,

Andrade AC, Kobayashi AK and Molinari HBC (2017) Overexpression of BdMATE Gene Improves Aluminum

Tolerance in Setaria viridis.

Front. Plant Sci. 8:865.

doi: $10.3389 / f p / s .2017 .00865$
1 Genetics and Biotechnology Laboratory, Embrapa Agroenergy, Brasilia, Brazil, ${ }^{2}$ Plant Biotechnology Program, Federal University of Lavras, Lavras, Brazil, ${ }^{3}$ Biomass and Biofuels Chemistry Laboratory, Embrapa Agroenergy, Brasilia, Brazil, ${ }^{4}$ Centre of Natural Sciences and Humanities, Federal University of ABC, São Bernardo do Campo, Brazil, ${ }^{5}$ Center of Genetic Engineering and Molecular Biology, Embrapa GenClima, University of Campinas, Campinas, Brazil, ${ }^{6}$ Applied Biology Center, Embrapa Maize and Sorghum, Sete Lagoas, Brazil, ${ }^{7}$ INOVACAFÉ, Embrapa Coffee, Lavras, Brazil

Acidic soils are distributed worldwide, predominantly in tropical and subtropical areas, reaching around $50 \%$ of the arable soil. This type of soil strongly reduces crop production, mainly because of the presence of aluminum, which has its solubility increased at low pH levels. A well-known physiological mechanism used by plants to cope with Al stress involves activation of membrane transporters responsible for organic acid anions secretion from the root apex to the rhizosphere, which chelate Al, preventing its absorption by roots. In sorghum, a membrane transporter gene belonging to multidrug and toxic compound extrusion (MATE) family was identified and characterized as an aluminum-activated citrate transporter gene responsible for Al tolerance in this crop. Setaria viridis is an emerging model for C4 species and it is an important model to validate some genes for further C4 crops transformation, such as sugarcane, maize, and wheat. In the present work, Setaria viridis was used as a model plant to overexpress a newly identified MATE gene from Brachypodium distachyon (BdMATE), closely related to SbMATE, for aluminum tolerance assays. Transgenic $S$. viridis plants overexpressing a BdMATE presented an improved Al tolerance phenotype, characterized by sustained root growth and exclusion of aluminum from the root apex in transgenic plants, as confirmed by hematoxylin assay. In addition, transgenic plants showed higher root citrate exudation into the rhizosphere, suggesting that Al tolerance improvement in these plants could be related to the chelation of the metal by the organic acid anion. These results suggest that BdMATE gene can be used to transform C4 crops of economic importance with improved aluminum tolerance.

Keywords: aluminum, Setaria viridis, MATE, abiotic stress, hydroponic system

Abbreviations: $\mathrm{Al}^{3+}$, trivalent aluminum; CIM, callus induction media; CS, citrate synthase; DTZ, distal transition zone; MATE, multidrug and toxic compound extrusion; MD, malate dehydrogenase; NT, non-transgenic; RGI, root growth inhibition; RNG, root net growth; SRM, selective regeneration medium; TCA, tricarboxylic acid. 


\section{INTRODUCTION}

Acidic soils are widely distributed worldwide, predominantly in tropical and subtropical areas, reaching around $50 \%$ of the arable soil in the world (Von Uexküll and Mutert, 1995; Cançado, 2006; Kochian et al., 2015). This type of soil strongly reduces crop production, mainly because of the presence of aluminum therein. Aluminum (Al) is the most abundant metal on Earth, and conjugated with oxides, silicates, and hydroxides constitutes soil particles (Boff, 2006; Oliveira, 2012). In highly acidic soils $(\mathrm{pH}<5), \mathrm{Al}$ is solubilized into a phytotoxic form $\mathrm{Al}\left(\mathrm{H}_{2} \mathrm{O}\right)_{6}{ }^{3+}$, usually referred to as $\mathrm{Al}^{3+}$. Aluminum is extremely rhizotoxic, affecting root growth and function and therefore limiting crop production and its toxicity, along with drought, is a primary food security concern (Von Uexküll and Mutert, 1995; Magalhães et al., 2007).

A well-known physiological mechanism used by plants to cope with $\mathrm{Al}$ stress involves the activation of plasma membrane transporters responsible for organic acid anions secretion from the root apex to the rhizosphere (Kochian et al., 2015). These anions form non-phytotoxic stable complexes with $\mathrm{Al}^{3+}$, preventing its absorption by the roots (Boff, 2006; Kochian et al., 2015). In sorghum (Sorghum bicolor), a membrane transporter gene belonging to the MATE family was identified and characterized as an aluminum-activated citrate transporter gene responsible for the $\mathrm{Al}$ tolerance in this crop, codifying for a proton-dependent transporter protein (Magalhães et al., 2007). Arabidopsis thaliana plants overexpressing the S. bicolor MATE gene (SbMATE) demonstrated an Al tolerant phenotype and increased root citrate exudation when compared to NT plants (Magalhães et al., 2007). These results support that a member of a MATE family from S. bicolor (SbMATE) is an $\mathrm{Al}$-activated citrate secretion transporter conferring aluminum tolerance. In addition, it was demonstrated that MATE homologs are root citrate transporters in other monocot species such as maize (ZmMATE1, Maron et al., 2010, 2013), and rice (OsFRD1, Yokosho et al., 2011). Moreover, the expression of the citrate transporters SbMATE and FDR3 in barley enhanced the $\mathrm{Al}$ tolerance in this sensitive cereal (Zhou et al., 2014). Other study demonstrated that a MATE gene cloned and isolated from Vigna umbellata (VuMATE), when expressed in tomato, was able to increase $\mathrm{Al}$ resistance, accompanied by enhanced citrate efflux (Yang et al., 2011). Currently, some physiological and molecular mechanisms of organic acid anions exudation are described. Several studies have implicated that plasma membrane $\mathrm{H}^{+}$-ATPases are involved in $\mathrm{Al}$ tolerance mechanism by citrate exudation. For instance, in soybean and broad bean, the citrate exudation from the roots was associated with the up-regulation of the plasma membrane $\mathrm{H}^{+}$-ATPase, indicating that this protein modulates $\mathrm{Al}$-induced citrate exudation (Shen et al., 2005; Chen et al., 2013, 2015). Wang et al. (2016) demonstrated that auxin is possibly involved in $\mathrm{Al}$ stress tolerance in soybean, since the concentration of IAA was increased by $\mathrm{Al}$ and exogenous application of IAA decreased $\mathrm{Al}$ concentration in roots by increasing citrate exudation through upregulation of GmMATE and activation of the plasma membrane $\mathrm{H}^{+}$ATPase. In addition to the well described SbMATE, a Brassica oleracea MATE gene has also been shown to be involved in $\mathrm{Al}$ tolerance responses in A. thaliana. Transgenic Arabidopsis lines overexpressing BoMATE demonstrated $\mathrm{Al}$ tolerance and increased citrate exudation. Furthermore, these lines showed a lower $\mathrm{K}^{+}$efflux and higher $\mathrm{H}^{+}$efflux in the presence of $\mathrm{Al}$, indicating that MATE is involved in the $\mathrm{K}^{+}$and $\mathrm{H}^{+}$fluxes during Al stress (Wu et al., 2014). Therefore, MATE, along with the anion channels ALMTs (Sasaki et al., 2004), are potential root organic acid anion transporters involved in $\mathrm{Al}$ resistance in plants and are potential targets for crop improvement under $\mathrm{Al}$ stress.

Setaria viridis is an emerging monocot plant model for molecular and genetic studies (Muthamilarasan and Prasad, 2015). It is a short, fast-growing, $C 4$ plant with its genome sequence fully available (Bennetzen et al., 2012), making it a reliable model for genetic studies. In addition, S. viridis is amenable for genetic transformation through Agrobacterium tumefaciens, with well-established transformation protocol (Martins et al., 2015). In the present work, S. viridis was used as a model plant system to overexpress a new ortholog of Sorghum bicolor MATE (SbMATE), Brachypodium distachyon MATE (BdMATE), under the control of the maize ubiquitin constitutive promoter (ZmUbi-1) for aluminum tolerance. The BdMATE gene was chosen because it is up-regulated under $\mathrm{Al}$ conditions (Contreras et al., 2014), whereas S. viridis MATE is not (this study, data not shown). The rationale was to use a close homolog of SbMATE and a patent-free gene, in order to use as proof of concept to further transform C4 crops of economic importance such as sugarcane, wheat, and maize, which are difficult and time-consuming to transform. S. viridis plants overexpressing BdMATE showed an Al tolerance phenotype, characterized by sustained root growth under $\{20\} \mu \mathrm{M} \mathrm{Al}^{3+}$, whereas NT plants showed RGI. Moreover, exclusion of aluminum from the root apex in transgenic plants was inferred based on results from hematoxylin assays. In addition, transgenic plants constitutively overexpressing BdMATE presented higher citrate secretion levels when compared to NT plants under Al stress, suggesting that the mechanism of organic acid anion exudation and consequent $\mathrm{Al}$ chelation by these compounds are involved in the $\mathrm{Al}$ toxicity amelioration in these plants. The expression of aluminum tolerance-related genes was evaluated, and the results obtained are discussed based on the known Al tolerance. Our results demonstrated that, in the future, the overexpression of BdMATE could be used to develop Al-tolerant crops closely related to S. viridis, such as maize, wheat, and sugarcane.

\section{MATERIALS AND METHODS}

\section{In Silico Analysis}

Searches for the Sorghum bicolor MATE (SbMATE) gene in the Phytozome database were performed in order to find orthologs in the genome of $B$. distachyon. Based on the different sequences found, the alignment of these sequences was generated using the Clustal Omega (Sievers and Higgins, 2014). Analysis of conserved protein domains and the prediction of the molecular and cellular functions of these domains were evaluated by the online softwares 
FFPred and MEMSAT (Nugent and Jones, 2009; Buchan et al., 2010). The phylogenetic tree was generated based on amino acid sequences of major grasses (Contreras et al., 2014) that have been studied with MATE gene, using the Geneious software (Kearse et al., 2012) for alignments and MEGA7 software (Kumar et al., 2016) for building phylogenetic tree.

\section{Tissue Culture and Plant Transformation}

In the present work, we were willing to validate an orthologous of the Sorghum bicolor MATE (SbMATE) gene that confers aluminum tolerance in different species (Magalhães et al., 2007; Sivaguru et al., 2013). The gene chosen was BdMATE, a close homolog of SbMATE from B. distachyon, a model organism for grasses (Kellogg, 2015), also studied by our group. The gene construct containing the $B$. distachyon MATE gene (BdMATE), driven by $Z m$ Ubil constitutive promoter and the $h p t$ gene selection marker (which confers hygromycin resistance), was synthetized by DNA Cloning Service, Germany (Supplementary Figure S1) and introduced into A. tumefaciens strain EHA105 for plant transformation.

Mature seeds of $S$. viridis accession A10.1 were selected for embryogenic calli induction in CIM [consisted of MS salts (Murashige and Skoog, 1962), $1 \mathrm{mg} / \mathrm{L}$ d-biotin, $0.5 \mathrm{mg} / \mathrm{L}$ pyridoxine $\mathrm{HCl}, 0.5 \mathrm{mg} / \mathrm{L}$ nicotinic acid, $100 \mathrm{mg} / \mathrm{L}$ myo-inositol, $0.1 \mathrm{mg} / \mathrm{L}$ thiamine- $\mathrm{HCl}, 0.6 \mathrm{mg} / \mathrm{L} \mathrm{CuSO}_{4}, 30 \mathrm{~g} / \mathrm{L}$ sucrose, $2 \mathrm{mg} / \mathrm{L}$ 2,4-dichlorophenoxyacetic acid, $0.5 \mathrm{mg} / \mathrm{L}$ kinetin, and $4 \mathrm{~g} / \mathrm{L}$ Phytagel $^{\mathrm{TM}}, \mathrm{pH}$ 5.8]. Induced calli were used for Agrobacteriummediated transformation, according to Martins et al. (2015). The putative transgenic calli, resistant to $30 \mathrm{mg} / \mathrm{L}$ hygromycin $\mathrm{B}$, were transferred to SRM consisting of MS salts (Murashige and Skoog, 1962), $1 \mathrm{mg} / \mathrm{L}$ d-biotin, $0.5 \mathrm{mg} / \mathrm{L}$ pyridoxine $\mathrm{HCl}, 0.5 \mathrm{mg} / \mathrm{L}$ nicotinic acid, $100 \mathrm{mg} / \mathrm{L}$ myo-inositol, $0.1 \mathrm{mg} / \mathrm{L}$ thiamine $\mathrm{HCl}$, $20 \mathrm{~g} / \mathrm{L}$ sucrose, $2 \mathrm{mg} / \mathrm{L}$ kinetin, $150 \mathrm{mg} / \mathrm{L}$ Timentin ${ }^{\circledR}$, $30 \mathrm{mg} / \mathrm{L}$ hygromycin B, 2 g/L Phytagel ${ }^{\mathrm{TM}}, \mathrm{pH}$ 5.8. The regenerated plants were submitted to PCR analysis in order to confirm the presence of the transgene.

\section{Molecular Analysis and Selection of the Transgenic Events}

Genomic DNA from regenerated plantlets resistant to hygromycin was extracted using a modified CTAB method (Doyle and Doyle, 1990), according to Molinari et al. (2007). The gene insertion was confirmed by PCR using specific primers designed for BdMATE amplification (Supplementary Table S1).

The putative transgenic events underwent gene expression analysis by real-time PCR of the target gene BdMATE, using the primers described in Supplementary Table S1. The expression level was calculated using endogenous genes $\mathrm{SiUBC}$ e SiSDH2 as reference (Martins et al., 2016).

Segregation analysis was performed in $T_{1}$ seeds to estimate the number of insertions in each event. Seeds were grown in selective medium with hygromycin B $50 \mathrm{mg} / \mathrm{L}$. After 7 days, the number of resistant and sensitive plants was counted, and the proportion was analyzed statistically using the $\chi$-Squared test. Events with single insertion determined by 3:1 Mendelian segregation ratio were selected. The $T_{2}$ seeds of the selected events were placed in selective medium with hygromycin B $50 \mathrm{mg} / \mathrm{L}$, for the selection of transgenic homozygous lines, which were used for aluminum stress assays.

\section{Aluminum Treatment Assay and Root Growth Measurement}

A protocol was established in order to evaluate the phenotype of $S$. viridis submitted to aluminum treatment in hydroponic system. First, NT 7-days-old plantlets were subjected to evaluation of root growth in different nutrient solutions such as Hoagland (Hoagland and Arnon, 1950), Camargo (Camargo, 1981), and Magnavaca (Magnacava et al., 1987) (Supplementary Figure S2). The growth of the plants under a solution based solely on $\mathrm{CaCl}_{2}$ (calcium chloride), at different concentrations, (Supplementary Figure S3) was also tested, according to Sasaki et al. (2004). The normal plant growth verified under $500 \mu \mathrm{M}$ $\mathrm{CaCl}_{2}$ solution prompted us to use it for our studies. $\mathrm{Al}^{3+}$ activity was estimated using the software GeoChem-EZ (Shaff et al., 2010) (Table 1 and Supplementary Figure S4). After the establishment of the stress protocol, a solution containing $\{20\} \mu \mathrm{M}$ of $\mathrm{Al}^{3+}$ free activity, $\mathrm{pH} 4.2$, was used to submit $S$. viridis plants to $\mathrm{Al}^{3+}$ for 1, 3, and 5 days, and this protocol was followed throughout the work. The evaluation of the root growth was performed by carefully scanning the roots daily for 5 days, in order not to damage the tissue, and the total root length was measured by the software WinRhizo 2007a (Régent Instruments). Transgenic and NT plants were evaluated for liquid root growth, and the percentage of RGI in treatments in the presence or absence of aluminum was calculated as described in Ryan et al. (2009). In order to measure RNG, the length of the roots was measured before and after each day of growth in the calcium chloride solution with $(+\mathrm{Al})$ and without $(-\mathrm{Al})$ aluminum. The \% RGI values were calculated from root growth measured over each day in $+\mathrm{Al}$ solution divided by root growth measured over each day in control $(-\mathrm{Al})$ solution $\times 100$, calculated individually for each plant.

\section{Real-Time qPCR Analysis}

After 7-days-old plantlets had been submitted to $500 \mu \mathrm{M}$ $\mathrm{CaCl}_{2}$ solution, in the absence or the presence of $\{20\} \mu \mathrm{M}$ $\mathrm{Al}^{3+}, \mathrm{pH}$ 4.2, in hydroponic system for 1, 3, and 5 days, total RNA was extracted from shoots using TRIzol ${ }^{\circledR}$ reagent (Thermo Fisher Scientific), according to the manufacturer's instructions. RNA from roots was extracted using a $\mathrm{LiCl}$ method

TABLE 1 | Concentration and free activity of aluminum in $500 \mu \mathrm{M}$ $\mathrm{CaCl}_{2} \cdot 2 \mathrm{H}_{2} \mathrm{O}$, pH 4.2, calculated using the software GeoChem-EZ (Shaff et al., 2010).

\begin{tabular}{lc}
\hline Concentrations of $\mathbf{A l C l}_{\mathbf{3}}$ & Free activity of $\mathbf{A l}^{\mathbf{3 +}}$ \\
\hline $0 \mu \mathrm{M}$ & $\{0\} \mu \mathrm{M}$ \\
$18 \mu \mathrm{M}$ & $\{10\} \mu \mathrm{M}$ \\
$35 \mu \mathrm{M}$ & $\{20\} \mu \mathrm{M}$ \\
\hline
\end{tabular}

Values inside the brackets indicate $A^{\beta+}$ activity estimated with the speciation software, GeoChem-EZ (Shaff et al., 2010). 
(Chang et al., 1993). The samples were treated with RQ1 RNasefree DNase (Promega, Madison, WI, USA), according to the manufacturer's instructions. Total RNA was quantified using a NanoDrop ND-1000 Spectrophotometer (Uniscience), and RNA integrity was verified in agarose gel electrophoresis. The synthesis of first strand CDNA was accomplished using the extracted RNA as template and the RevertAid ${ }^{\mathrm{TM}}$ First Strand cDNA Synthesis kit (Thermo Fisher Scientific). These steps were all performed according to the manufacturer's instructions. The qPCR was carried out using Platinum ${ }^{\circledR}$ SYBR $^{\circledR}$ Green PCR SuperMix-UDG with ROX (Invitrogen, Carlsberg, CA, USA) with synthesized single-stranded cDNA as template, using the protocol recommended by the StepOnePlusReal-Time PCR Systems (Applied Biosystems). The primers used in the qPCR are described in Supplementary Table S1.

Relative gene expression levels were calculated using the q-Gene (Muller et al., 2002). SiEF1- $\alpha$; SiSUI, SiCAC, and SiCUL were used as reference genes (Martins et al., 2016) and the geometrical mean of the relative quantities (RQs) was calculated using BestKeeper software (Pfaffl et al., 2004). Individual amplification efficiencies were established with LinRegPCR v.2013.0 using a window-of-linearity (Ramakers et al., 2003). The experiment was performed using three biological replicates, with 40 plants each.

\section{Hematoxylin Staining}

The exudation of organic acid anions by the root apex will act chelating aluminum in the rhizosphere, forming a neutral complex, thus preventing the root absorption of part of the Al. Staining is described as one of the best and fastest methods to monitor the location and aluminum distribution in plants (Illés et al., 2006). The hematoxylin method was used to evaluate $\mathrm{Al}$ accumulation in $S$. viridis plants under aluminum treatment, similar to treatment described above carried out for root growth measurement. The protocol was based on Tang et al. (2000). The roots were excised from the plantlets and gently shaken in $2 \mathrm{~mL}$ of distilled water for $60 \mathrm{~min}$. The water was replaced by $2 \mathrm{~mL}$ of aqueous hematoxylin solution $(0.2 \%$ hematoxylin and $0.02 \%$ potassium iodide, w/v) and agitated for $15 \mathrm{~min}$. Finally, the solution was replaced one more time by $2 \mathrm{~mL}$ distilled water, thereby repeating the first step. After staining, the roots were photographed under the stereomicroscopic Leica Model S8APO.

\section{Determination of Root Citrate Exudation}

The transgenic and the NT plants were grown hydroponically as described previously, and root exudates were collected after 3 days of growth on nutrient solution containing $\{0\}$ or $\{20\}$ $\mu \mathrm{M} \mathrm{Al}^{3+}$. After the exposure period, the roots were washed with $20 \mathrm{~mL}$ of $500 \mu \mathrm{M} \mathrm{CaCl}_{2}$ solution for $40 \mathrm{~min}$, under $60 \mathrm{rpm}$ in an orbital shaker. This procedure was repeated three times for each replicate. Each replicate (3 in total) was composed of 40 plantlets bulked together for extraction (120 plantlets in total). The extraction was normalized to the root biomass for each line. The solutions were lyophilized for organic acids analysis on a gas chromatography-mass spectrometry (GC-MS) system (Varian GC 3800 and MS 2000). The lyophilized material were washed in pure methanol and dried under vacuum. To the dried samples were added $100 \mu \mathrm{L}$ of pyridine and $50 \mu \mathrm{L}$ of BSTFA (N,O-bis(trimethylsilyl)trifluoroacetamide) + 1\% TMCS (trimethylchlorosilane). The analysis of GC/MS was performed according to Centeno et al. (2016) on a $30 \mathrm{~m} \mathrm{HP} 5$ column with $0.25 \mathrm{~mm}$ of diameter and $0.25 \mu \mathrm{M}$ film thickness (Supelco). Helium was used as the carrier gas at a flow rate of $1 \mathrm{~mL} \mathrm{~min}^{-1}$. The analysis was performed under the following temperature program: $5 \mathrm{~min}$ of isothermal heating at $70^{\circ} \mathrm{C}$, followed by a

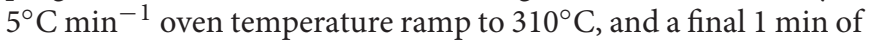
heating at $310^{\circ} \mathrm{C}$. Mass spectra were recorded at 2 scan s$^{-1}$ with a scanning range of $50-600 \mathrm{~m} / \mathrm{z}$. Both chromatograms and mass spectra were evaluated using the OpenChrom software (Wenig and Odermatt, 2010). The peaks were identified and quantified in comparison with authentic standards and the NIST 08 Mass Spectral Library.

\section{Statistical Analysis}

Experimental data were analyzed using randomized block design (RBD) with replications for each treatment $(\{0\}$ and $\{20\} \mu \mathrm{M}$ $\mathrm{Al}^{3+}$ ). Samples for all analysis were collected at days 1, 3, and 5 . Differences among treatments per sample were analyzed using $t$-test, considering $p<0.05$ as significant.

\section{RESULTS}

\section{In Silico Analysis}

In order to find orthologous sequences of $S$. bicolor MATE gene, it was conducted a BLAST analysis in the Phytozome database $^{1}$. The hits based on the lowest $E$-values, highest score values and larger alignment bars with the query sequence were chosen for alignment studies using the MATE genes present in different organisms. B. distachyon (BdMATE) gene showed a close similarity to the SbMATE gene (Supplementary Figure S5), and therefore BdMATE was chosen for further studies. S. viridis MATE gene was not chosen because the expression levels of the endogenous SvMATE did not change in the presence of $\mathrm{Al}$ under our experimental conditions (see below). The selected amino acid sequence of $B$. distachyon MATE protein (BdMATE - Bradilg69770.1) were aligned using the Geneious software (Kearse et al., 2012) with the different MATE sequences from other related organisms to generate a phylogenetic tree, using MEGA7 software (Kumar et al., 2016) (Figure 1A). The sequence Bradilg69770.1 was chosen for the present study due to its close similarity to the $S$. bicolor MATE sequence.

In addition, BdMATE and SbMATE transmembrane domains analysis was performed, using the softwares FFPRED and MEMSAT-SVM (Nugent and Jones, 2009; Buchan et al., 2010). The results are shown in the Figure 1B, where it was demonstrated that the $B$. distachyon MATE possesses the same 12 transmembrane domains presented by the $S$. bicolor MATE protein. BdMATE belongs to the large multifunctional transport family involved in the transport of organic solutes out of

\footnotetext{
${ }^{1}$ http://phytozome.jgi.doe.gov
} 


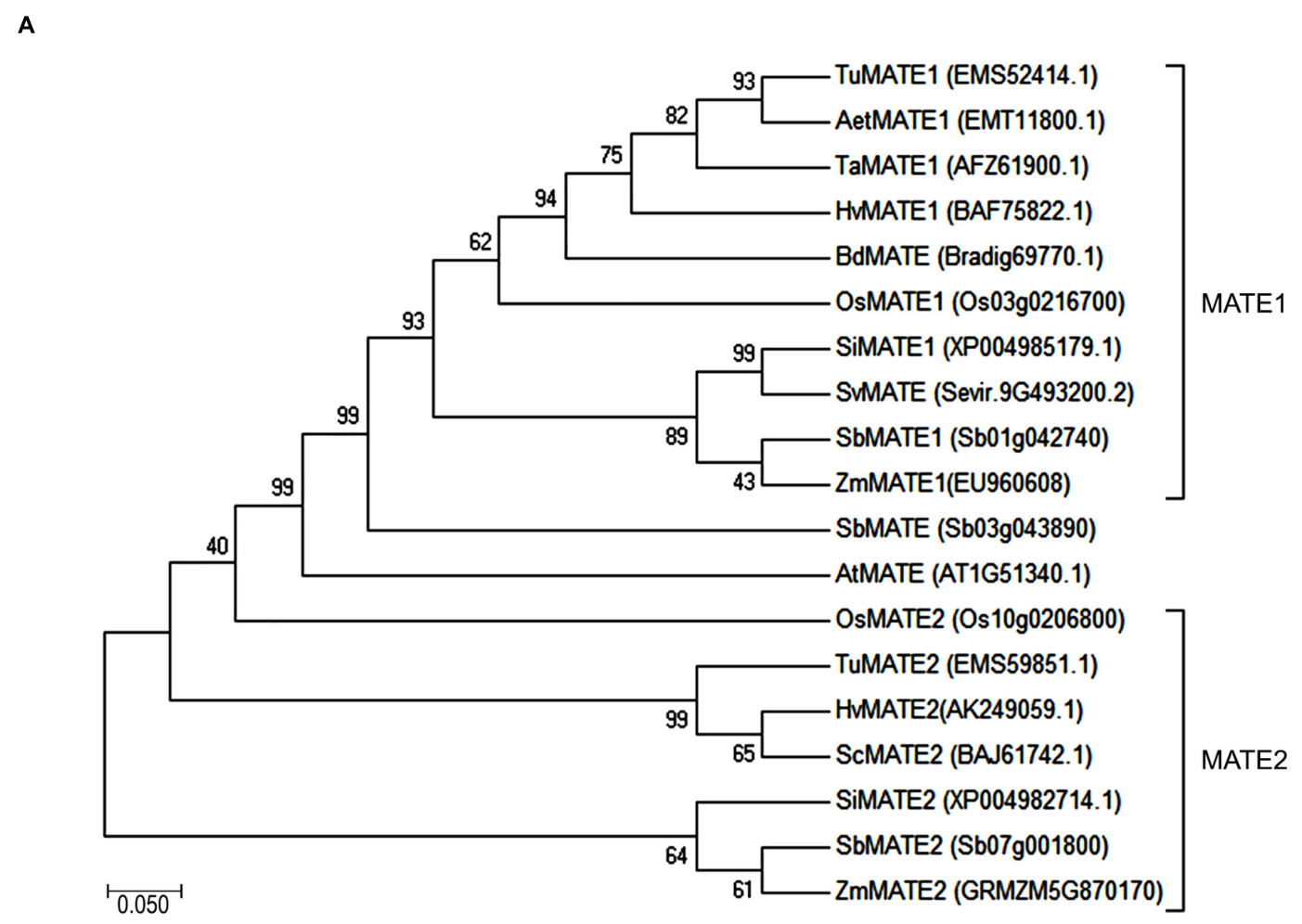

B
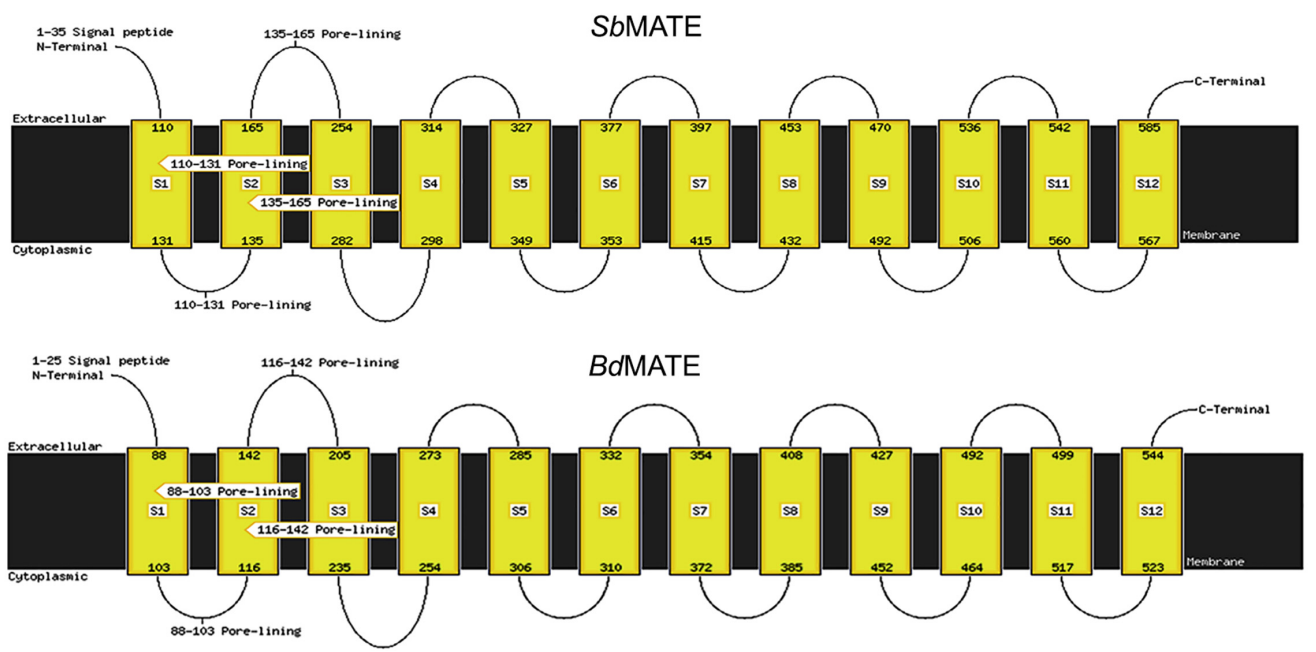

FIGURE 1 | (A) Phylogenetic tree based on amino acid sequences. The analyses were conducted in MEGA7 software (Kumar et al., 2016) using the Maximum Likelihood method and bootstrap consensus tree inferred from 10000 replicates. The amino acids sequences of these proteins were obtained from NCBI and Phytozome. (B) Transmembrane domains of the BdMATE and SbMATE generated by FFPRED and MEMSAT-SVM (Nugent and Jones, 2009; Buchan et al., 2010).

the cytoplasm. The putative molecular functions attributed to this protein are transporter activity, ion transmembrane transporter activity, receptor activity, and lipid binding; all these characteristics have shown high specificity and precision for BdMATE, according to MEMSAT (McGuffin et al., 2000; Nugent and Jones, 2009).

\section{Generation of BdMATE Transgenic Lines}

After the similarity between BdMATE and SbMATE has been confirmed by in silico analysis, an expression vector containing $Z m$ Ubil::BdMATE was constructed in order to transform embryogenic calli of $S$. viridis accession A10.1. Transgenic calli were selected with $30 \mathrm{mg} / \mathrm{L}$ of hygromycin $\mathrm{B}$ and regenerated 
under SRM. Genomic DNA was extracted from regenerated plants and used as template for PCR using primers designed for the BdMATE gene amplification. The $450 \mathrm{bp}$ amplification product corresponding to the specific region of the BdMATE gene was confirmed in the transgenic plants (Supplementary Figure S6A). The gene expression levels were analyzed by qPCR using BdMATE specific primers for $30 T_{0}$ transgenic events. Representative events expressing different levels of BdMATE were selected for Mendelian segregation analysis. All the selected events showed a 3:1 segregation ratio, indicating a single gene insertion (Supplementary Figure S6B and Table S2).

Subsequently, the events 28 and 29, showing moderate and high expression levels of BdMATE, respectively, were chosen to generate homozygous lines. Two different homozygous lines at $T_{3}$ generation were obtained, 28.1 and 29.2. The expression of the BdMATE gene in these homozygous lines was evaluated in S. viridis roots using real-time quantitative PCR (Supplementary Figure S7A) and these lines were chosen for further aluminum tolerance tests.

\section{Aluminum Tolerance Evaluation in Transgenic Plants}

The most common criterion used to measure $\mathrm{Al}$ toxicity is the comparison of the root length of Al-affected plants with control plants grown in the absence of aluminum (Ma et al., 1997). In the present study, homozygous $S$. viridis transgenic plants overexpressing the BdMATE gene were evaluated by measuring the root growth along 5 days in a hydroponic system in the absence or presence of $\{20\} \mu \mathrm{M} \mathrm{Al}^{3+}$ free activity, in comparison to NT plants. The results demonstrated that transgenic lines presented higher root length compared with NT plants in the presence of $\mathrm{Al}$ (Figure 2A). In the absence of the metal, both NT plants and the transgenic line 29.2 showed a similar root growth pattern, while the line 28.1 demonstrated a lower root growth even in control conditions (Figures 2A,B).

Quantification of the relative net root growth (RNRG; Figure 3A) and the percentage of the RGI (Figure 3B) confirmed the Al tolerance phenotype demonstrated by $B d M A T E$ transgenic plants. It is worth to mention that the morphology of the roots was not affected from the constitutive expression of the BdMATE gene. A RGI above $90 \%$ was observed in NT plants after 5 days in $\{20\} \mu \mathrm{M} \mathrm{Al}{ }^{3+}$ (Figure 3B). Under the same conditions, transgenic plants overexpressing BdMATE demonstrated from 30 to $65 \%$ of RGI for the events 28.1 and 29.2. According to Magalhães et al. (2007), a plant can be considered tolerant to $\mathrm{Al}$ when its RGI during the stress is $\leq 70 \%$. It is worth to mention that transgenic plants grown in the presence of $\mathrm{Al}$ demonstrated a small decrease of root elongation when compared to NT plants, indicating that BdMATE overexpression did not fully eliminate the toxic effects of $\mathrm{Al}$, but ameliorates such effect.

\section{Hematoxylin Staining}

Hematoxylin assay was performed after $24 \mathrm{~h}$ of plants exposed to $\{0\}$ or $\{20\} \mu \mathrm{M} \mathrm{Al}^{3+}$. This assay consists of the development of blue-purplish color in areas where aluminum is present in the root tissue. The Figure $\mathbf{3 A}$ shows accumulation of aluminum in a larger root portion of $S$. viridis NT plants in the presence of $\mathrm{Al}(+\mathrm{Al})$, while in the transgenic plants in the same conditions the blue-purplish color representing $\mathrm{Al}$ accumulation is absent. The staining of the plants is not observed in plants not submitted to $\mathrm{Al}$ (Figure $\mathbf{3 A} ;-\mathrm{Al}$ ). These results suggest that NT plants are accumulating higher concentrations of Al than transgenic plants, indicating that tolerant plants are avoiding the absorption of $\mathrm{Al}$ by the roots.

\section{Root Citrate Exudation}

The measurements of root citrate secretion demonstrated that a new MATE homolog, BdMATE, when overexpressed in S. viridis plants, was able to increase the levels of this anion in transgenic plants when compared to NT plants (Figure 3B). In the presence of $\{20\} \mu \mathrm{M} \mathrm{Al}{ }^{3+}$, the transgenic lines presented a threefold increase of citrate exudation in comparison to the NT plants, suggesting that BdMATE plants are conferring $\mathrm{Al}$ tolerance through the mechanism of citrate release into the rhizosphere.

\section{Gene Expression Analysis TCA Cycle Genes}

The Figure 4 demonstrated that no difference of CS (SiCS) and MD $(S i M D)$ gene expression levels were observed between transgenic and NT plants, in the absence or presence of Al. The signaling of Al tolerance in plants is still a matter of debate and therefore more studies are necessary in order to elucidate the relationship between the levels of citrate produced by the TCA cycle with Al tolerance in plants. The results obtained on gene expression levels will be discussed in the latter section.

\section{Expression of Endogenous S. viridis MATE Gene}

The expression levels of endogenous $S$. viridis MATE gene (Sevir.9g493200.2) were verified to demonstrate the involvement of SvMATE in Al stress responses. The Supplementary Figure S7B shows that SvMATE expression levels did not change in plants submitted to $\mathrm{Al}$ when compared to plants in the absence of the cation, indicating that the endogenous SvMATE does not participate in aluminum stress responses in S. viridis. Although the similarity of the MATE sequence of S. viridis and B. distachyon is $83.2 \%$ (Supplementary Figure S8).

\section{DISCUSSION}

Sugarcane is a very important economic crop for Brazil nowadays. Brazil is the largest sugarcane producer worldwide, and its production is intended mainly for ethanol and sugar production. In addition, the biomass released from the sugarcane process can be used as lignocellulosic material to be degraded by microorganisms to generate renewable fuels and addedvalue products. Despite of its great importance, the regions for sugarcane growth in Brazil are becoming scarce. An alternative for growing sugarcane could be the Cerrado region, characterized by its soil with acidic $\mathrm{pH}$. Therefore, a great effort has been made by the scientific community in order to improve sugarcane traits for its growth in poor soils. Setaria viridis is an emerging model 
A

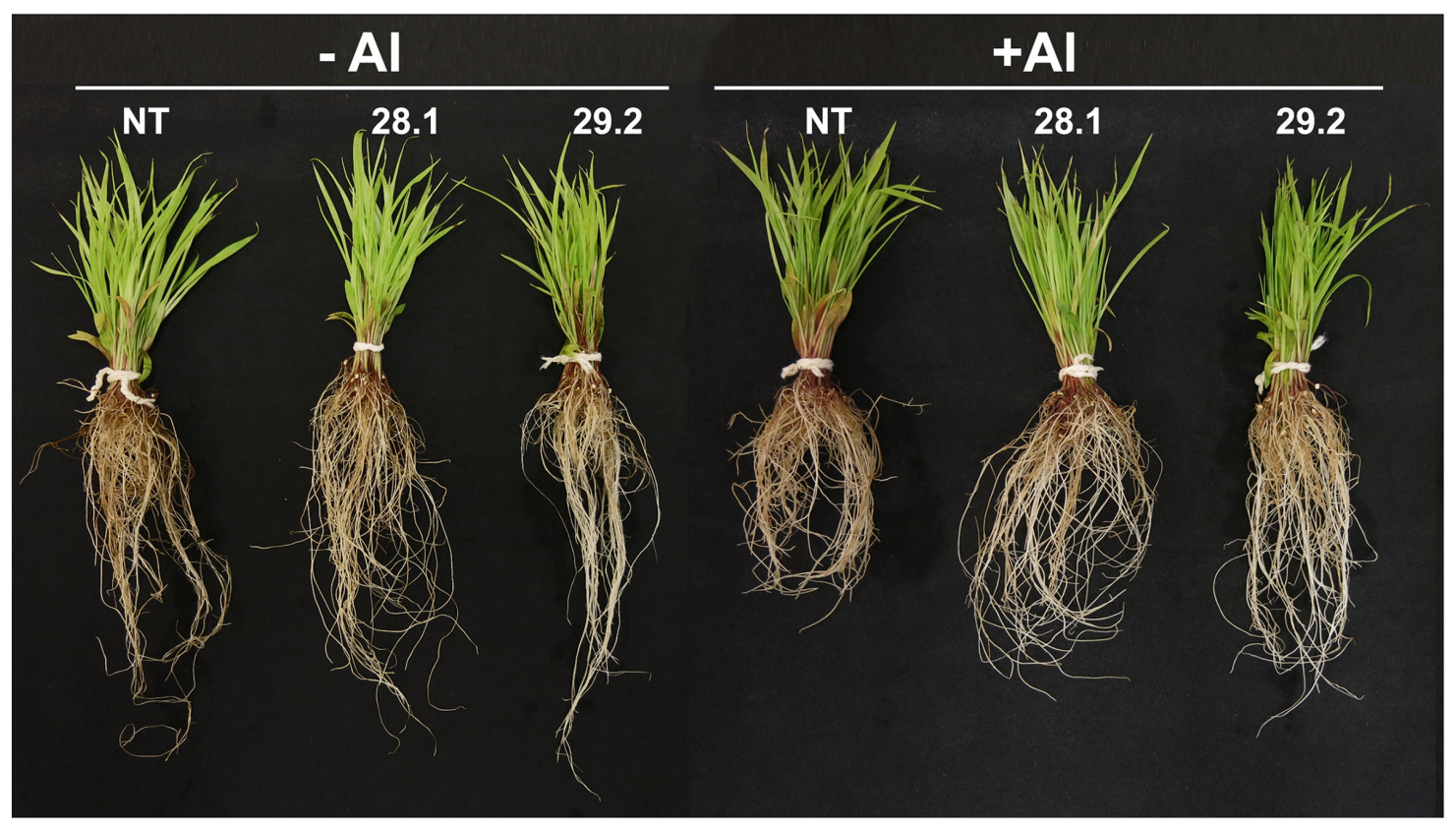

B

C
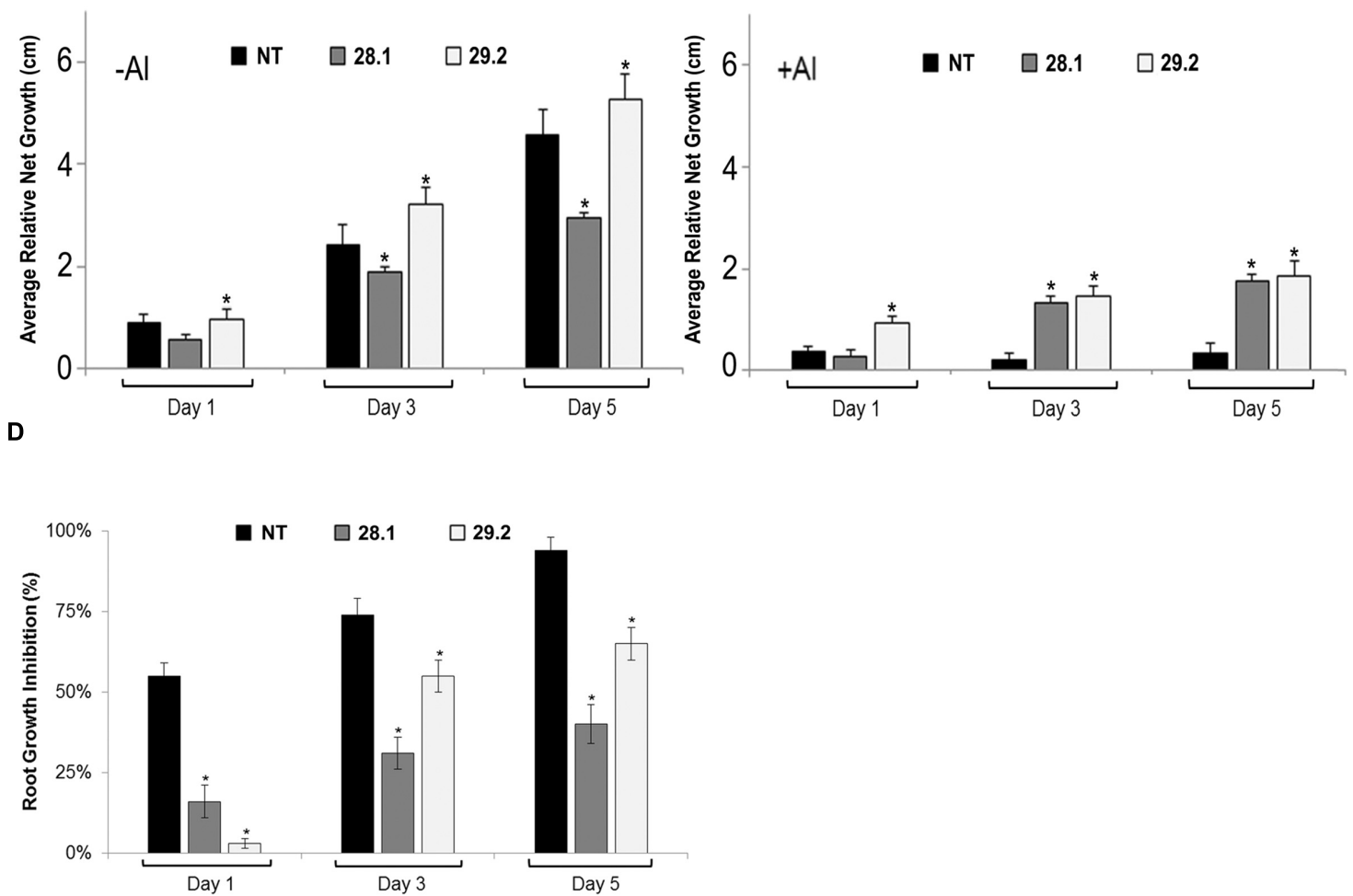

FIGURE 2 | (A) Setaria viridis homozygous transgenic lines overexpressing BdMATE and NT plants in the absence (-Al; left panel) and after 5 days of exposure to $\left.\{20\} \mu \mathrm{M} \mathrm{A}\right|^{3+}$ (+Al; right panel). (B,C) Relative RNG of S. viridis homozygous transgenic lines overexpressing BdMATE and NT plants grown under the absence (-Al) or presence (+Al) of $\left.\{20\} \mu \mathrm{M} \mathrm{A}\right|^{3+}$ during 1, 3, and 5 days. The length of the roots was measured before and after each day of growth in the calcium chloride solution with $(+\mathrm{Al})$ and without $(-\mathrm{Al})$ aluminum $(n=20$ plantlets). (D) RGI of $S$. viridis homozygous transgenic lines overexpressing BdMATE and NT plants grown under the absence $(-\mathrm{Al})$ or presence (+Al) of $\{20\} \mu \mathrm{M} \mathrm{Al}{ }^{3+}$ during 1,3 , and 5 days. The $\%$ RGI values were calculated from root growth measured over each day in $+\mathrm{Al}$ solution divided by root growth measured over each day in control (-Al) solution $\times 100$, calculated individually for each plant $(n=20$ plantlets). *Significantly different at $P<0.05$ between $-\mathrm{Al}$ and + Al treatments in transgenic lines. 

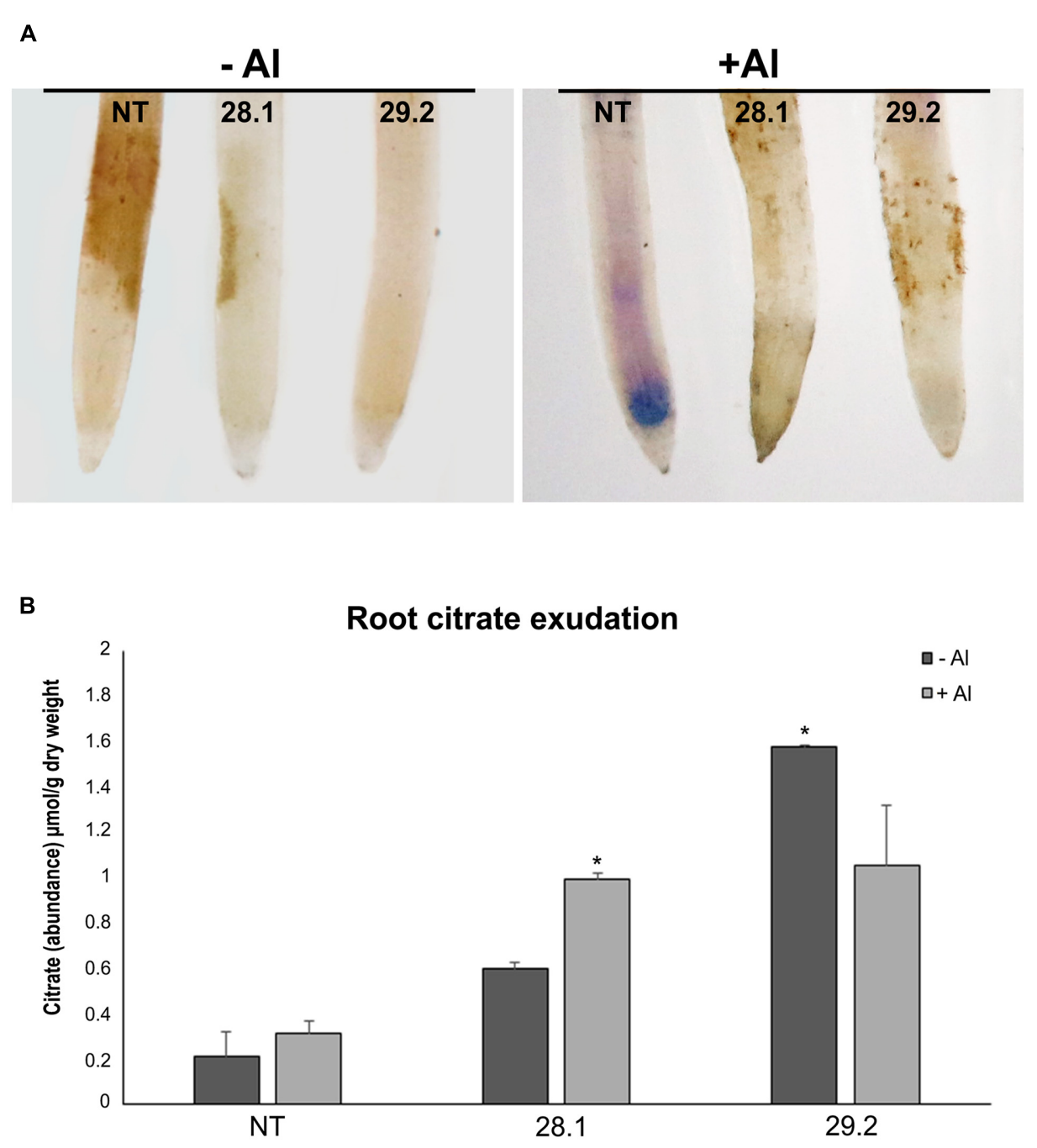

FIGURE 3 | (A) Hematoxylin staining after 24 h exposure to $\{0\}$ and $\{20\} \mu M \mathrm{Al}^{3+}$ in roots of the S. viridis homozygous transgenic lines overexpressing BdMATE and NT plant. (B) Citrate abundance on roots exudates in the absence and after 3 days of exposure to $\{20\} \mu \mathrm{M} \mathrm{Al}{ }^{3+}$. Citric acid was determined by gas chromatography/mass spectrometry (GC/MS). The values are represented as the mean $\pm \mathrm{SD}$. * Significantly different at $P<0.05$ between $-\mathrm{Al}$ and $+\mathrm{Al}$ treatments in transgenic lines.

for C4 species and it is an important model to validate some genes for further sugarcane transformation (Muthamilarasan and Prasad, 2015). In the present work, a close homolog of SbMATE gene, the $B$. distachyon MATE gene (BdMATE) was constitutively overexpressed in Setaria viridis (Brutnell et al., 2010), in order to verify aluminum tolerance in transgenic plants. The BdMATE gene was chosen instead of the $S$. viridis MATE gene (SvMATE) because $B d M A T E$ is a close homolog of SbMATE expressed under Al conditions (Contreras et al., 2014), while SvMATE is not (this study, data not shown). The results obtained with the overexpression of BdMATE in S. viridis plants clearly showed an $\mathrm{Al}$ tolerance phenotype in these plants (Figure 2). The main symptom of aluminum toxicity is inhibition of root growth, which is observed consistently in plants sensitive to this metal (Kochian et al., 2015). In the presence of Al, the two different homozygous transgenic lines demonstrated higher root length
(Figure 2A) and RNRG (Figures 2B,C) when compared to NT plants. On the other hand, the percentage of RGI of transgenic plants under $\mathrm{Al}$ stress was lower when compared to the control (Figure 2D). However, it is worth to mention that the root growth of transgenic lines was lower in the presence of $\mathrm{Al}$ than in the absence of this metal, indicating that BdMATE ameliorates but do not completely eliminates the phytotoxicity effect of this cation.

Furthermore, hematoxylin staining, a common method used to monitor the location and aluminum accumulation in plants (Illéš et al., 2006), demonstrated that BdMATE plants did not accumulate $\mathrm{Al}$ in the root apex, a phenotype demonstrated by NT plants (Figure 3B). The primary site of aluminum accumulation and damage is still a matter of debate. In many species, the root apex was identified as the primary site of perception of aluminum toxicity, and consequently the expression of tolerance 


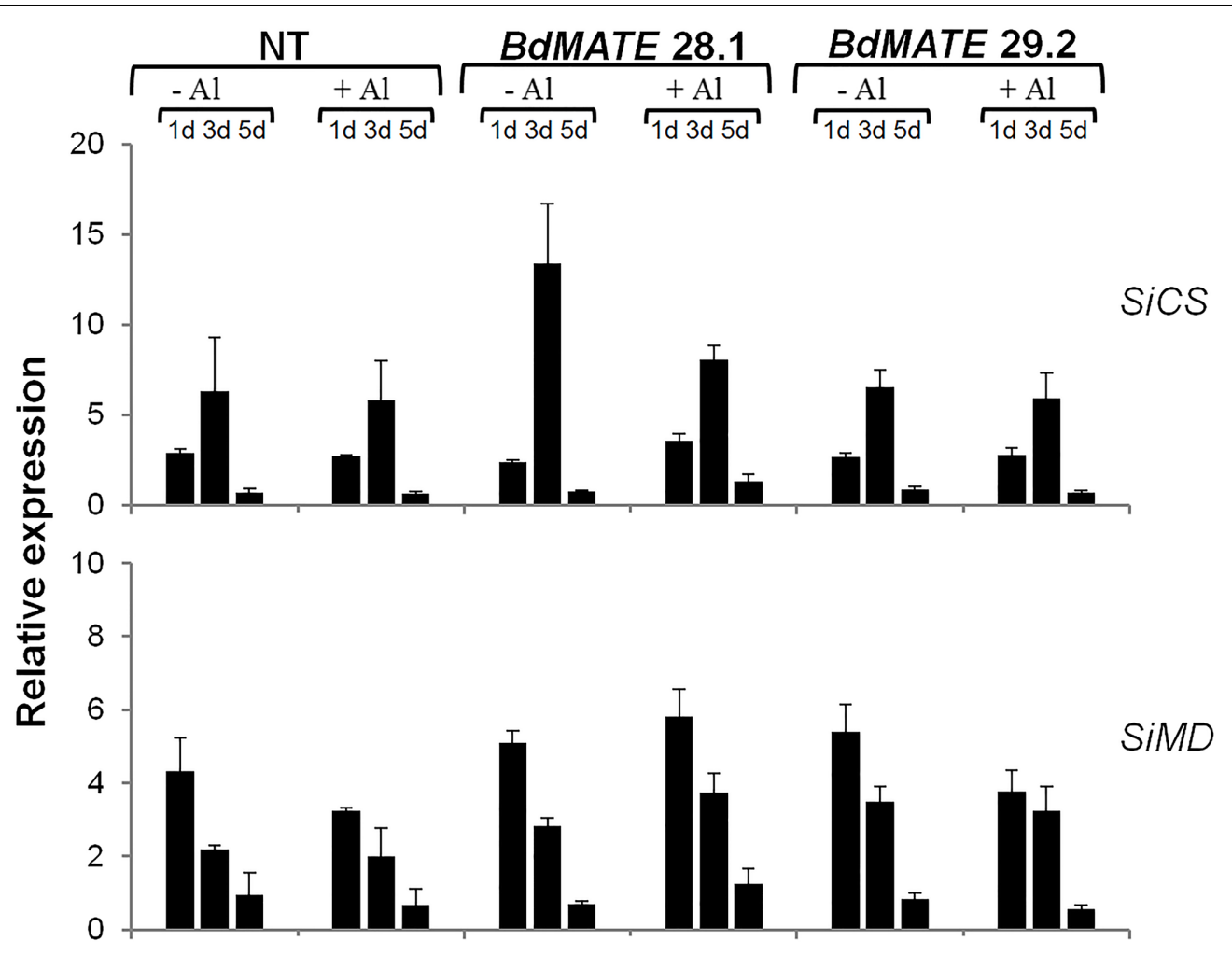

FIGURE 4 | Relative gene expression levels of the SiCS (CS) and SiMD (MD) in the S. viridis homozygous transgenic lines overexpressing BdMATE and NT plants submitted to $\{0\}$ and $\{\mathbf{2 0}\} \mu \mathbf{M} \mathbf{A l}^{\mathbf{3}+}$ during $\mathbf{1}, \mathbf{3}$, and $\mathbf{5}$ days. No significant difference at $P<0.05$ between $-\mathrm{Al}$ and $+\mathrm{Al}$ treatments in transgenic lines.

(Kollmeier et al., 2000; Yang et al., 2008; Horst et al., 2010; Motoda et al., 2011; Souza et al., 2016). Sivaguru et al. (2013) demonstrated that $\mathrm{Al}$ affects approximately the $1-3 \mathrm{~mm}$ portion of the roots in sorghum lines sensitive to the metal. Although the effects of aluminum may occur in all parts of the root growing regions, ruptures above pea (Yamamoto et al., 2001), maize (Jones et al., 2006), and bean roots (Kopittke et al., 2008) occurred predominantly in regions within about $1-2 \mathrm{~mm}$ of the root tip, in the distal portion known by the DTZ (Sivaguru and Horst, 1998). In order to effectively confer Al resistance via Al-activated citrate exudation, it is logical to assume that the highest density of root citrate transporters should be specifically located in the root regions most affected by Al toxicity (Sivaguru et al., 2013). Our hematoxylin staining results also showed that the portion of $\mathrm{Al}$ accumulation in roots of $S$. viridis NT plants occurs in the DTZ (Figure 3A). Thus, it is worth to verify the gene expression profile of target genes related to Al tolerance in different portions of $S$. viridis roots in non-transformed or transgenic plants submitted to $\mathrm{Al}$ stress, an approach that is currently being performed by our group.

As described above, the exudation of organic acid anions by the root apex is a common mechanism to confer $\mathrm{Al}$ tolerance in plants, as these compounds are able to chelate this metal in the rhizosphere, avoiding root absorption. It was demonstrated that MATE homologs were root citrate transporters in different monocot species such as maize and rice (Maron et al., 2010,
2013; Yokosho et al., 2011). Here, it was demonstrated that a new MATE homolog, BdMATE, when overexpressed in S. viridis plants, was able to increase root citrate exudation in transgenic plants when compared to NT plants. We verified the exudation of citrate, the major organic acid anion secreted through the MATE transporter (Magalhães et al., 2007; Kochian et al., 2015) in $S$. viridis plants in the absence or presence of Al. Our results confirmed that transgenic plants overexpressing the BdMATE gene secreted more citrate than NT plants in both conditions (Figure 3B). Organic acids are metabolically active solutes with a diverse array of functions in many organisms. These acids have a potential role in the osmotic adjustment and in the balance of cation concentration of the cells, for instance. As described above, OAs anions are secreted by the root apex as an aluminum resistance mechanism in most plants. Citrate, malate, and oxalate are the main OAs anions secreted to the rhizosphere in many plant species (Kochian et al., 2015). Organic acids (OAs) are produced mainly in the mitochondria, by the TCA cycle and, in a lesser extent, in the glyoxysome (López-Bucio et al., 2000). The accumulation of OAs produced by TCA cycle is dependent upon the plant species, age of the plant and tissue type. In addition, the exudation of OAs anions by roots is dependent on the route of involvement of these OAs in specific physiological functions (Rees, 1990; López-Bucio et al., 2000). Recently, NunesNesi et al. (2014) discussed the involvement of enzymes of the TCA cycle in response to the stress of aluminum, since OAs 
participate as key components in the mechanisms that some plants use to cope with nutritional deficiency and metal tolerance. Since citrate and malate are the main OAs anions secreted to the rhizosphere under $\mathrm{Al}$ stress, we aimed to investigate the expression levels of genes related to $\mathrm{CS}$ and $\mathrm{MD}$, responsible for citrate and malate production, respectively, in the transgenic plants overexpressing BdMATE. It could be possible that the tolerance phenotype presented by transgenic plants under $\mathrm{Al}$ stress was due to an increased expression of genes responsible for the production of citrate or malate by these plants. However, we were not able to verify any difference in the gene expression levels between transgenic and NT plants, in the absence or presence of $\mathrm{Al}$ (Figure 4).

The relationship between increased $\mathrm{CS}$ activity and $\mathrm{Al}$ tolerance is still inconclusive. In some species such as Triticum aestivum L. (wheat) and Secale cereale L. (rye), the evaluation of CS production in aluminum stress conditions have been performed aluminum (Li et al., 2000). Plantlets of cv. King of the $S$. cereale demonstrated an increased CS activity when exposed to aluminum for more than $6 \mathrm{~h}$, while in cv. Atlas 66 of the T. aestivum L. there was no difference in enzyme activity in plantlets subjected to aluminum (Ryan et al., 1993; Li et al., 2000). Our results demonstrated that $S$. viridis transgenic plants overexpressing BdMATE with Al tolerance phenotype do not increase the levels of CS gene expression. As mentioned above, the OAs that the plant uses in order to tolerate the aluminum through exudation by the root apex are metabolites originated in the TCA cycle, a key metabolic pathway to all organisms. Thus, it is plausible that the tolerance mechanism to aluminum in plants has a significant carbon cost, being highly regulated (Ryan et al., 1993; Sivaguru and Horst, 1998; Magalhães et al., 2007; Sivaguru et al., 2013). The CS gene is constantly being expressed to maintain the balance between citrate production and consumption by the cell. The product of the CS gene, citrate, is a molecule that is converted rapidly in the TCA cycle and/or can be degraded in other cellular compartments to ensure that the metabolic system may be constantly supplied (negative feedback). Thus, it could be very difficult to observe drastic changes in the expression levels of a gene that is involved in a fine-tune regulation of pivotal metabolic processes in the cell. Therefore, more studies are necessary in order to elucidate the relationship between the levels of citrate produced by the TCA cycle with $\mathrm{Al}$ tolerance in plants. We were not able to measure if the transformed plants had a carbon loss penalty compared to NT plants, especially because the experiments were performed in hydroponic conditions during a

\section{REFERENCES}

Bennetzen, J. L., Schmutz, J., Wang, H., Percifield, R., Hawkins, J., Pontaroli, A. C., et al. (2012). Reference genome sequence of the model plant Setaria. Nat. Biotechnol. 30, 555-561. doi: 10.1038/nbt.2196

Boff, T. (2006). Tolerância ao Alumínio em Trigo: Identificação e Caracterização Molecular de Genes. Ph.D. thesis, Universidade Federal do Rio Grande do Sul, Porto Alegre.

Brutnell, T. P., Wang, L., Swartwood, K., Goldschmidt, A., Jackson, D., Zhu, X. G., et al. (2010). Setaria viridis: a model for C4 photosynthesis. Plant Cell 22, 2537-2544. doi: 10.1105/tpc.110.075309 short time. We are currently establishing Al stress experiments in soil to further study the biomass of plants transformed with $B d M A T E$. In addition, root-specific and/or Al-induced promoters are being currently studied by our group, to minimize the putative carbon loss caused by the constitutive expression of BdMATE.

Altogether, our results suggest that a $\mathrm{C} 4$ plant overexpressing a $B$. distachyon MATE transporter gene (BdMATE) was more tolerant to aluminum stress than wild plants through the exudation of citrate into the rhizosphere, with subsequent avoidance of $\mathrm{Al}$ absorption and accumulation in the DTZ of the roots. As consequence, the transgenic plants demonstrated sustainable root growth in the presence of $\mathrm{Al}$ when compared to NT plants. Our results suggested that, in the future, the overexpression of BdMATE could be used to develop Al tolerant crops closely related to $S$. viridis such as maize, wheat, and sugarcane.

\section{AUTHOR CONTRIBUTIONS}

HM, AK, AR, PM, WRS, and AA conceived and designed the experiments. $\mathrm{PM}$ and $\mathrm{AR}$ performed the in silico analysis. AR, WRS, FV, and KD performed the abiotic stress assays. AR, BC, and FV carried out the RT-qPCR assays and analyzed the data. AR, PM, WRS, and AK performed hematoxylin assay. PAO, RC, DC, WRS, MB, and HM performed and analyzed the organic acids. WRS and AR wrote the manuscript. AR, WRS, GC, JVM, $\mathrm{CS}, \mathrm{MB}$, and $\mathrm{AA}$ contributed to the discussion of the results. $\mathrm{HM}, \mathrm{AK}$, and GC provided intellectual input and revised the manuscript. All authors read and approved the final manuscript.

\section{FUNDING}

This work was supported by the Brazilian Agricultural Research Corporation (Embrapa), the Brazilian Federal Agency for Graduate Education (CAPES), and the São Paulo ResearchFoundation (FAPESP) grant Proc. n. 2012/23838-7.

\section{SUPPLEMENTARY MATERIAL}

The Supplementary Material for this article can be found online at: http://journal.frontiersin.org/article/10.3389/fpls.2017.00865/ full\#supplementary-material

Buchan, D. W., Ward, S. M., Lobley, A. E., Nugent, T. C. O., Bryson, K., and Jones, D. T. (2010). Protein annotation and modelling servers at University College London. Nucleic Acids Res. 38, W563-W568. doi: 10.1093/nar/gkq427

Camargo, C. E. D. O. (1981). Melhoramento do trigo: I. Hereditariedade da tolerância à toxicidade do alumínio. Bragantia 40, 33-45. doi: 10.1590/S000687051981000100004

Cançado, G. M. A. (2006). Caracterização e Utilização de Genes Envolvidos na Tolerância ao Alumínio Tóxico em Milho. Ph.D. thesis, Universidade Estadual de Campinas, Campinas.

Centeno, D. C., Hell, A. F., Braga, M. R., Del Campo, E. M., and Casano, L. M. (2016). Contrasting strategies used by lichen microalgae to cope with 
desiccation-rehydration stress revealed by metabolite profiling and cell wall analysis. Environ. Microbiol. 18, 1546-1560. doi: 10.1111/1462-2920.13249

Chang, S., Puryear, J., and Cairney, J. (1993). A simple and efficient method for isolating RNA from pine trees. Plant Mol. Biol. Rep. 11, 113-116. doi: 10.1007/ BF02670468

Chen, Q., Guo, C. L., Wang, P., Chen, X. Q., Wu, K. H., Li, K. Z., et al. (2013). Up-regulation and interaction of the plasma membrane $\mathrm{H}+$-ATPase and the 14-3-3 protein are involved in the regulation of citrate exudation from the broad bean (Vicia faba L.) under Al stress. Plant Physiol. Biochem. 70, 504-511. doi: 10.1016/j.plaphy.2013.06.015

Chen, Q., Kan, Q., Wang, P., Yu, W., Yu, Y., Zhao, Y., et al. (2015). Phosphorylation and interaction with the 14-3-3 protein of the plasma membrane H+-ATPase are involved in the regulation of magnesium-mediated increases in aluminuminduced citrate exudation in broad bean (Vicia faba L). Plant Cell Physiol. 56, 1144-1153. doi: 10.1093/pcp/pcv038

Contreras, R., Figueiras, A. M., Gallego, F. J., and Benito, C. (2014). Brachypodium distachyon: a model species for aluminium tolerance in Poaceae. Funct. Plant Biol. 41, 1270-1283. doi: 10.1071/FP13362

Doyle, J. J., and Doyle, J. L. (1990). Isolation of plant DNA from fresh tissue. Focus $12,13-15$.

Hoagland, D. R., and Arnon, D. I. (1950). The Water-Culture Method for Growing Plants Without Soil, 2nd Edn. Berkeley, CA: University of California, 347.

Horst, W. J., Wang, Y., and Eticha, D. (2010). The role of the root apoplast in aluminium-induced inhibition of root elongation and in aluminium resistance of plants: a review. Ann. Bot. 106, 185-197. doi: 10.1093/aob/mcq053

Illéš, P., Schlicht, M., Pavlovkin, J., Lichtscheidl, I., Baluška, F., and Oveèka, M. (2006). Aluminium toxicity in plants: internalization of aluminium into cells of the transition zone in Arabidopsis root apices related to changes in plasma membrane potential, endosomal behaviour, and nitric oxide production. J. Exp. Bot. 57, 4201-4213. doi: 10.1093/jxb/erl197

Jones, D. L., Blancaflor, E. B., Kochian, L. V., and Gilroy, S. (2006). Spatial coordination of aluminium uptake, production of reactive oxygen species, callose production and wall rigidification in maize roots. Plant Cell Environ. 29, 1309-1318. doi: 10.1111/j.1365-3040.2006.01509.x

Kearse, M., Moir, R., Wilson, A., Stones-Havas, S., Cheung, M., Sturrock, S., et al. (2012). Geneious basic: an integrated and extendable desktop software platform for the organization and analysis of sequence data. Bioinformatics 28 , 1647-1649. doi: 10.1093/bioinformatics/bts199

Kellogg, E. A. (2015). Brachypodium distachyon as a genetic model system. Annu. Rev. Genet. 49, 1-20. doi: 10.1146/annurev-genet-112414-055135

Kochian, L. V., Piñeros, M. A., Liu, J., and Magalhaes, J. V. (2015). Plant adaptation to acid soils: the molecular basis for crop aluminum resistance. Annu. Rev. Plant Biol. 66, 571-598. doi: 10.1146/annurev-arplant-043014114822

Kollmeier, M., Felle, H. H., and Horst, W. J. (2000). Genotypical differences in aluminum resistance of maize are expressed in the distal part of the transition zone. Is reduced basipetal auxin flow involved in inhibition of root elongation by aluminum? Plant Physiol. 122, 945-956. doi: 10.1104/pp.122.3.945

Kopittke, P. M., Blamey, F. P. C., and Menzies, N. W. (2008). Toxicities of soluble $\mathrm{Al}, \mathrm{Cu}$, and La include ruptures to rhizodermal and root cortical cells of cowpea. Plant Soil 303, 217-227. doi: 10.1007/s11104-007-9500-5

Kumar, S., Stecher, G., and Tamura, K. (2016). MEGA7: molecular evolutionary genetics analysis version 7.0 for bigger datasets. Mol. Biol. Evol. 33, 1870-1874. doi: $10.1093 / \mathrm{molbev} / \mathrm{msw} 054$

Li, X. F., Ma, J. F., and Matsumoto, H. (2000). Pattern of aluminum-induced secretion of organic acids differs between rye and wheat. Plant Physiol. 123, 1537-1544. doi: 10.1104/pp.123.4.1537

López-Bucio, J., Nieto-Jacobo, M. F., Ramírez-Rodríguez, V., and HerreraEstrella, L. (2000). Organic acid metabolism in plants: from adaptive physiology to transgenic varieties for cultivation in extreme soils. Plant Sci. 160, 1-13. doi: 10.1016/S0168-9452(00)00347-2

Ma, J. F., Zheng, S. J., Li, X. F., Takeda, K., and Matsumoto, H. (1997). A rapid hydroponic screening for aluminium tolerance in barley. Plant Soil 191, 133-137. doi: 10.1023/A:1004257711952

Magalhães, J. V., Liu, J., Guimarães, C. T., Lana, U. G., Alves, V. M., Wang, Y. H., et al. (2007). A gene in the multidrug and toxic compound extrusion (MATE) family confers aluminum tolerance in sorghum. Nat. Genet. 39, 1156-1161. doi: $10.1038 / \mathrm{ng} 2074$
Magnacava, R., Gardner, C. O., and Clark, R. B. (1987). "Evaluation of inbred maize lines for aluminum in nutrient solution," in Genetics Aspects of Plant Mineral Nutrition, eds H. W. Gabelman and B. C. Loughman (Dordrecht: Martinus Nijhoff Publishers), 255-265.

Maron, L. G., Guimarães, C. T., Kirst, M., Albert, P. S., Birchler, J. A., Bradbury, P. J., et al. (2013). Aluminum tolerance in maize is associated with higher MATE1 gene copy number. Proc. Natl. Acad. Sci. U.S.A. 110, 5241-5246. doi: 10.1073/pnas.1220766110

Maron, L. G., Piñeros, M. A., Guimarães, C. T., Magalhaes, J. V., Pleiman, J. K., Mao, C., et al. (2010). Two functionally distinct members of the MATE (multi-drug and toxic compound extrusion) family of transporters potentially underlie two major aluminum tolerance QTLs in maize. Plant J. 61, 728-740. doi: 10.1111/j.1365-313X.2009.04103.x

Martins, P. K., Mafra, V., De Souza, W. R., Ribeiro, A. P., Vinecky, F., Basso, M. F., et al. (2016). Selection of reliable reference genes for RT-qPCR analysis during developmental stages and abiotic stress in Setaria viridis. Sci. Rep. 6:28348. doi: $10.1038 /$ srep 28348

Martins, P. K., Ribeiro, A. P., da Cunha, B. A. D. B., Kobayashi, A. K., and Molinari, H. B. C. (2015). A simple and highly efficient Agrobacteriummediated transformation protocol for Setaria viridis. Biotechnol. Rep. 6, 41-44. doi: 10.1016/j.btre.2015.02.002

McGuffin, L. J., Bryson, K., and Jones, D. T. (2000). The PSIPRED protein structure prediction server. Bioinformatics 16, 404-405. doi: 10.1093/bioinformatics/16.4. 404

Molinari, H. B. C., Marur, C. J., Daros, E., De Campos, M. K. F., De Carvalho, J. F. R. P., Pereira, L. F. P., et al. (2007). Evaluation of the stress-inducible production of proline in transgenic sugarcane (Saccharum spp.): osmotic adjustment, chlorophyll fluorescence and oxidative stress. Physiol. Plant. 130, 218-229. doi: 10.1111/j.1399-3054.2007.00909.x

Motoda, H., Kano, Y., Hiragami, F., Kawamura, K., and Matsumoto, H. (2011). Changes in rupture formation and zonary region stained with Evans blue during the recovery process from aluminum toxicity in the pea root apex. Plant Signal. Behav. 6, 98-100. doi: 10.4161/psb.6.1.14148

Muller, P. Y., Janovjak, H., Miserez, A. R., and Dobbie, Z. (2002). Processing of gene expression data generated by quantitative real-time RT-PCR. Biotechniques 32, 1372-1374.

Murashige, T., and Skoog, F. (1962). A revised medium for rapid growth and bio assays with tobacco tissue cultures. Physiol. Plant. 15, 473-497. doi: 10.1111/j. 1399-3054.1962.tb08052.x

Muthamilarasan, M., and Prasad, M. (2015). Advances in Setaria genomics for genetic improvement of cereals and bioenergy grasses. Theor. Appl. Genet. 128, 1-14. doi: 10.1007/s00122-014-2399-3

Nugent, T., and Jones, D. T. (2009). Transmembrane protein topology prediction using support vector machines. BMC Bioinformatics 10:159. doi: 10.1186/14712105-10-159

Nunes-Nesi, A., Brito, D. S., Inostroza-Blancheteau, C., Fernie, A. R., and Araújo, W. L. (2014). The complex role of mitochondrial metabolism in plant aluminum resistance. Trends Plant Sci. 19, 399-407. doi: 10.1016/j.tplants.2013. 12.006

Oliveira, M. D. S. (2012). Tolerância de Variedades de Cana-De-Açúcar (Saccharum spp.) à Toxidez por Aluminio em Solução. Master, dissertation, Universidade Federal de São Carlos, Araras.

Pfaffl, M. W., Tichopad, A., Prgomet, C., and Neuvians, T. P. (2004). Determination of stable housekeeping genes, differentially regulated target genes and sample integrity: BestKeeper-Excel-based tool using pair-wise correlations. Biotechnol. Lett. 26, 509-515. doi: 10.1023/B:BILE.0000019559.84305.47

Ramakers, C., Ruijter, J. M., Deprez, R. H. L., and Moorman, A. F. (2003). Assumption-free analysis of quantitative real-time polymerase chain reaction (PCR) data. Neurosci. Lett. 339, 62-66. doi: 10.1016/S0304-3940(02)01423-4

Rees, T. A. P. (1990). "Carbon metabolism in mitochondria," in Plant Physiology, Biochemistry and Molecular Biology, eds D. T. Dennis and D. H. Turpin (Essex: Longman Scientific and Technical), 106-111.

Ryan, P. R., Ditomaso, J. M., and Kochian, L. V. (1993). Aluminium toxicity in roots: an investigation of spatial sensitivity and the role of the root cap. J. Exp. Bot. 44, 437-446. doi: 10.1093/jxb/44.2.437

Ryan, P. R., Raman, H., Gupta, S., Horst, W. J., and Delhaize, E. (2009). A second mechanism for aluminum resistance in wheat relies on the constitutive efflux of citrate from roots. Plant Physiol. 149, 340-351. doi: 10.1104/pp.108.129155 
Sasaki, T., Yamamoto, Y., Ezaki, B., Katsuhara, M., Ahn, S. J., Ryan, P. R., et al. (2004). A wheat gene encoding an aluminum-activated malate transporter. Plant J. 37, 645-653. doi: 10.1111/j.1365-313X.2003.01991.x

Shaff, J. E., Schultz, B. A., Craft, E. J., Clark, R. T., and Kochian, L. V. (2010). GEOCHEM-EZ: a chemical speciation program with greater power and flexibility. Plant Soil 330, 207-214. doi: 10.1007/s11104-009-0193-9

Shen, H., He, L. F., Sasaki, T., Yamamoto, Y., Zheng, S. J., Ligaba, A., et al. (2005). Citrate secretion coupled with the modulation of soybean root tip under aluminum stress. Up-regulation of transcription, translation, and threonineoriented phosphorylation of plasma membrane H+-ATPase. Plant Physiol. 138, 287-296. doi: 10.1104/pp.104.058065

Sievers, F., and Higgins, D. G. (2014). Clustal Omega, accurate alignment of very large numbers of sequences. Multiple Seq. Align. Methods 1079, 105-116. doi: 10.1007/978-1-62703-646-7_6

Sivaguru, M., and Horst, W. J. (1998). The distal part of the transition zone is the most aluminum-sensitive apical root zone of maize. Plant Physiol. 116, 155-163. doi: 10.1104/pp.116.1.155

Sivaguru, M., Liu, J., and Kochian, L. V. (2013). Targeted expression of SbMATE in the root distal transition zone is responsible for sorghum aluminum resistance. Plant J. 76, 297-307. doi: 10.1111/tpj.12290

Souza, L. T. D., Cambraia, J., Ribeiro, C., Oliveira, J. A. D., and Silva, L. C. D. (2016). Effects of aluminum on the elongation and external morphology of root tips in two maize genotypes. Bragantia 75, 19-25. doi: 10.1590/1678-4499.142

Tang, Y., Sorrells, M. E., Kochian, L. V., and Garvin, D. F. (2000). Identification of RFLP markers linked to the barley aluminum tolerance gene. Crop Sci. 40, 778-782. doi: 10.2135/cropsci2000.403778x

Von Uexküll, H. R., and Mutert, E. (1995). Global extent development and economic-impact of acid soils. Plant Soil 171, 115. doi: 10.1007/BF00009558

Wang, P., Yu, W., Zhang, J., Rengel, Z., Xu, J., Han, Q., et al. (2016). Auxin enhances aluminium-induced citrate exudation through upregulation of GmMATE and activation of the plasma membrane H+-ATPase in soybean roots. Ann. Bot. 118, 933-940. doi: 10.1093/aob/mcw133

Wenig, P., and Odermatt, J. (2010). OpenChrom: a cross-platform open source software for the mass spectrometric analysis of chromatographic data. BMC Bioinformatics 11:405. doi: 10.1186/1471-2105-11-405
Wu, X., Li, R., Shi, J., Wang, J., Sun, Q., Zhang, H., et al. (2014). Brassica oleracea MATE encodes a citrate transporter and enhances aluminum tolerance in Arabidopsis thaliana. Plant Cell Physiol. 55, 1426-1436. doi: 10.1093/pcp/ pcu067

Yamamoto, Y., Kobayashi, Y., and Matsumoto, H. (2001). Lipid peroxidation is an early symptom triggered by aluminum, but not the primary cause of elongation inhibition in pea roots. Plant Physiol. 125, 199-208. doi: 10.1104/pp.125.1.199

Yang, J. L., Li, Y. Y., Zhang, Y. J., Zhang, S. S., Wu, Y. R., Wu, P., et al. (2008). Cell wall polysaccharides are specifically involved in the exclusion of aluminum from the rice root apex. Plant Physiol. 146, 602-611. doi: 10.1104/pp.107.111989

Yang, X. Y., Yang, J. L., Zhou, Y., Piñeros, M. A., Kochian, L. V., Li, G. X., et al. (2011). A de novo synthesis citrate transporter, Vigna umbellata multidrug and toxic compound extrusion, implicates in Al-activated citrate efflux in rice bean (Vigna umbellata) root apex. Plant Cell Environ. 34, 2138-2148. doi: 10.1111/j. 1365-3040-2011-02410.x

Yokosho, K., Yamaji, N., and Ma, J. F. (2011). An Al-inducible MATE gene is involved in external detoxification of $\mathrm{Al}$ in rice. Plant J. 68, 1061-1069. doi: 10.1111/j.1365-313X.2011.04757.x

Zhou, G., Pereira, J. F., Delhaize, E., Zhou, M., Magalhães, J. V., and Ryan, P. R. (2014). Enhancing the aluminium tolerance of barley by expressing the citrate transporter genes SbMATE and FRD3. J. Exp. Bot. 65, 2381-2390. doi: 10.1093/ jxb/eru121

Conflict of Interest Statement: The authors declare that the research was conducted in the absence of any commercial or financial relationships that could be construed as a potential conflict of interest.

Copyright (c) 2017 Ribeiro, de Souza, Martins, Vinecky, Duarte, Basso, da Cunha, Campanha, de Oliveira, Centeno, Cançado, de Magalhães, de Sousa, Andrade, Kobayashi and Molinari. This is an open-access article distributed under the terms of the Creative Commons Attribution License (CC BY). The use, distribution or reproduction in other forums is permitted, provided the original author(s) or licensor are credited and that the original publication in this journal is cited, in accordance with accepted academic practice. No use, distribution or reproduction is permitted which does not comply with these terms. 